\title{
Annual cycle of the production and fate of DMS and DMSP in a marine coastal system
}

\author{
Rik L. J. Kwint ${ }^{1,2, *}$, Kees J. M. Kramer ${ }^{2, * *}$ \\ ${ }^{1}$ University of Groningen, Department of Microbiology, PO Box 14,9750 AA Haren, The Netherlands \\ ${ }^{2}$ TNO Institute of Environmental and Energy Research and Process Innovation, Department for Ecological Risk Studies, \\ PO Box 57, 1780 AB Den Helder, The Netherlands
}

\begin{abstract}
The production of DMSP by phytoplankton and the fate through the marine system of both DMSP and DMS were followed for a period of $21 \mathrm{mo}$ in the natural environment by studying a Wadden Sea tidal inlet. The major production and emission of DMS appeared to be limited to a period of only $2 \mathrm{mo}$, which was closely linked to the presence of phytoplankton blooms. The production of DMS in the water column was not well correlated with chlorophyll a concentrations or plankton species composition. It was however, found to be closely related to the start of a Phaeocystis bloom early in spring. Contrary to our expectations, the senescence phase of this Phaeocystis bloom did not result in high DMS accumulation. It is postulated that this phenomenon could be the result of a bacterial consumption which increased with time in combination with a decreasing DMSP-lyase activity of Phaeocystis. A simple model, into which the overall DMSP consumption could be untroduced, could very well imitate the measured concentrations of DMS in the water column of the natural system studied.
\end{abstract}

KEY WORDS: Dimethylsulphoniopropionate - Dimethylsulphide Phytoplankton · Consumption . Phaeocystis . Annual cycle

\section{INTRODUCTION}

The production of dimethylsulphide (DMS) and its release into the air constitutes one of the most important biogenic sources of sulphur to the atmosphere. It is formed from the precursor DMSP ( $\beta$-dimethylsulphoniopropionate), which has a presumed osmoregulating or cryoprotecting function in marine algae (Dacey et al. 1987, Gröne \& Kirst 1992, Baumann et al. 1994).

In the atmosphere, DMS can be oxidized to non sea salt sulphates and methane sulphonic acid which can be responsible for formation of cloud condensation nuclei, or CCN, which influence cloud formation and the backscattering of solar radiation and, thus, may have an influence on climate (Charlson et al. 1987 , Caldeira 1989, Legrand et al. 1991, Malin et al. 1992).

There appears to be no direct correlation between chlorophyll a (chl a) and DMS concentration in oceanic surface waters (Dacey \& Wakeham 1986, Turner et al.

\footnotetext{
•E-mail: lamr@kribc.tno.nl

- Present address: Mermayde, PO Box 109, 1860 AK Bergen, The Netherlands
}

1989, Bürgermeister et al. 1990, Leck et al. 1990). This makes it difficult to predict global DMS quantities by means of biomass estimations from remote sensing data. DMSP is associated with some algal species but there is a wide variation in the potential for algae to produce it. Diatoms are generally considered to be unimportant producers of DMSP, while other algal classes, including Dinophyceae and Prymnesiophyceae, are considered to produce relatively large amounts of DMSP and DMS (Keller et al. 1989, Gibson et al. 1990, Matrai \& Keller 1993, 1994, Stefels \& van Boekei 1993). Factors which control the release of DMS into the water are not clearly understood, but possible mechanisms are: metabolic excretion, algal senescence and zooplankton grazing activity (Dacey \& Wakeham 1986, Nguyen et al. 1988, Belviso et al. 1990, 1993, Stefels \& van Boekel 1993, Levasseur et al. 1994). Loss factors for DMSP and DMS from the water column are bacterial consumption of DMS and DMSP, ventilation into the atmosphere and photochemical oxidation of DMS. Sedimentation of particulate DMSP $\left(\right.$ DMSP $_{\mathrm{p}}$ ) can also occur (Brimblecombe \& Shooter 1986, Kiene 1990, 1992, Kiene \& Service 1991, Belviso et al. 1993, Osinga et al. 1996). 
Kwint \& Kramer (1995) showed, in several experiments carried out in marine pelagic mesocosms, that a maximum release of DMS occurred directly after a phytoplankton bloom, during the senescence phase. In order to extrapolate these results to larger systems such as the North Sea, we monitored phytoplankton. blooms over a period of 21 mo (November 1991 to July 1993), thereby taking in 2 phytoplankton spring blooms in the Marsdiep channel, a tidal inlet of the Dutch Wadden Sea. Our main goal was to see whether predictions are possible on a larger (natural) scale for the release of DMS through this extrapolation, taking into account the seasonal cycle of DMS and DMSP. Due to the length of the monitoring period, the results form a unique data set. In addition, mesocosm experiments were carried out with water from the same location (Kwint \& Kramer 1995).

\section{MATERIALS AND METHODS}

Samples were collected in the Marsdiep tidal inlet from November 1991 to November 1992 (Series I) and from January to June 1993 (Series II) a few hundred metres off the coast of Den Helder, The Netherlands Sampling was intended to take place at 10:00 h and at high tide in order to rule out any tidal or diurnal effects. This automatically implied a sampling interval of about 2 wk. After it became clear that changes in DMS concentration could occur very rapidly, the frequency was changed. Sampling was attempted at high tide as often as was logistically possible from the start of the phytoplankton spring bloom in 1993 (March to June)

Water samples were collected in a $10 \mathrm{I}$ bucket that was rinsed thoroughly with seawater prior to sampling. Subsamples for chl a, phytoplankton, and DMS and DMSP were immediately taken from this large sample.

Chl a subsamples were stored in 11 polyethylene bottles in the dark, until analysis, which took place within $2 \mathrm{~h}$. One litre samples were filtered over glass fibre filters (Whatman GF/C), extracted with $90 \%$ acetone and analyzed on a spectrophotometer according to standard procedures (Parsons et al. 1984)

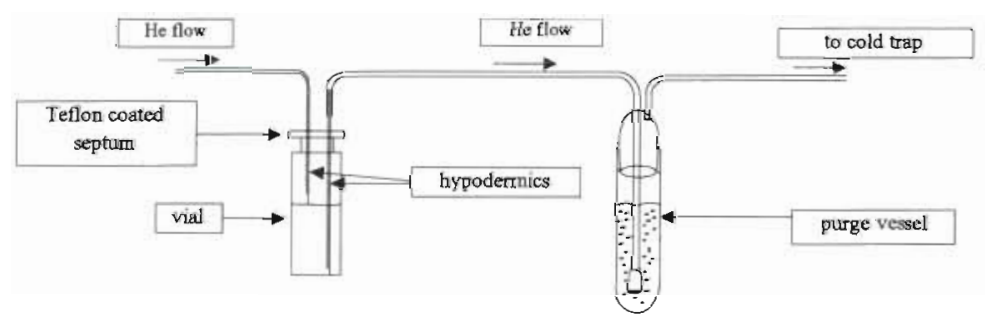

Fig. 1. Diagram of method used to transfer DMSP samples to the normal purge-trap system
Samples for the phytoplankton species identification were preserved and stored with Lugol's until further examination. Phytoplankton were identified and counted in a $5 \mathrm{ml} \mathrm{Kolkwicz} \mathrm{chamber} \mathrm{under} \mathrm{an} \mathrm{inverted}$ microscope. For each sample at least 20 fields were counted (magnification $400 \times$ )

Subsamples for the determination DMS and DMSP were taken in 1 l, dark, glass stoppered bottles and stored on ice until further treatment. The samples were treated immediately after returning to the laboratory (usually within $2 \mathrm{~h}$ ). A subsample of 10 to $25 \mathrm{ml}$ was gently filtered over a Whatman GF/C filter. It was considered important that no pressure or suction was applied in order to minimize interference resulting from damaged cells. DMS was purged from the filtered water sample by using high grade helium. The helium, containing the volatile compounds and water vapour, was dried by means of a Nafion permeation drier (Perma Pure Products, Farmingdale, USA) with nitrogen as the drying gas. After drying, the volatile compounds were collected on a cryogenic trap consisting of a straight glass tube containing Tenax-ta (Chrompack, Middelburg, The Netherlands) according to Kwint \& Kramer (1995). After collection, the Tenax tube was closed with Swagelock caps and stored in liquid nitrogen until analysis (adapted from Lindqvist 1989). Storage tests with calibration gas showed that samples can be stored thus for at least $8 \mathrm{wk}$ without detectable change

To determine the concentration of dissolved DMSP $\left(\right.$ DMSP $_{\mathrm{d}}$ ) a $10 \mathrm{ml}$ subsample from the purged filtrate was placed in a $20 \mathrm{ml}$ vial, which, after addition of $1 \mathrm{ml}$ $10 \mathrm{M} \mathrm{NaOH}$ (Dacey \& Blough 1987), was immediately closed with a Teflon coated septum. The vials were stored at $4^{\circ} \mathrm{C}$ until analysis. After hydrolysis by the $\mathrm{NaOH}$, the sample was moved from the vial to the purge vessel in a closed system by means of 2 hypodermic needles and the helium flow (see Fig. 1). The complete sample could be analyzed without any loss of DMS to the gas phase by using this procedure.

A $10 \mathrm{ml}$ unfiltered seawater sample was hydrolysed in a similar way in order to assess the total amount of DMSP + DMS. The DMSP concentration was calculated by subtracting the DMS and DMSP ${ }_{d}$ concentration. Thus in principle DMSP $\mathrm{D}_{\mathrm{p}}$ consists of all intra cellular DMSP, DMSP adsorbed to detritus and that incorporated into zooplankton and zooplankton faecal pellets.

DMS was analyzed according to Lindquist (1989) on a Varian 3500 gas-chromatograph equipped with $10 \mathrm{~m}$ Poraplot-U capillary (0.53/0.7 $\mathrm{mm}$ inside/outside diameter) column (Chrompack) and a photo-ionization detector (10.2 eV, HNU Systems Inc., Newton, MA, USA). Hydrogen was used as the carrier gas. The detection limit was 1.5 pmol 
DMS. The coefficients of variation (CV) for the DMS analyses for independent analyses were no larger than $5 \%$ for samples with a concentration over $100 \mathrm{nM}$, and $17 \%$ for samples with a concentration below this value (Kwint \& Kramer 1995).

Fluxes of DMS to the atmosphere were calculated from the water concentrations and from wind speeds (daily averages) obtained from a meteorological station near the sampling site, using the Liss/Slater model (Liss \& Slater 1974).

\section{RESULTS AND DISCUSSION}

Fig. 2 shows the results for the chl a and DMS measurements for both Series I and II. During the winter period, DMS and chl a in these coastal waters showed relatively low background values as compared to the spring/summer values (chl a about $2.5 \mathrm{~kg} \mathrm{^{-1 }}$, DMS below $0.5 \mathrm{nM}$ ) for both years. Each spring (March), the chl a as well as the DMS concentration started to rise and a maximum was reached within $1 \mathrm{mo}$

During Series I (1992), maximum chl a (20 $\left.\mathrm{gg} \mathrm{l}^{-1}\right)$ and DMS concentrations (17 nM) coincided. During Series II we found similar values for chl a $\left(18 \mu \mathrm{gl}^{-1}\right)$ and DMS (18 $\mathrm{nM}$ ) around the same date. The sampling frequency was increased in this period and it was found that a peak in the chl a concentration $\left(30 \mu \mathrm{g} \mathrm{I^{-1 }}\right)$ preceded the DMS peak by about $5 \mathrm{~d}$. The maximum chl a and DMS concentrations in both years (DMS measured in duplicate) appear to be in surprisingly good agreement. Also, the very steep increase in the concentration of DMS was found for both years. Furthermore, these results agree well with the seasonal variations measured by Leck et al. (1990) for spring/summer data in the Baltic Sea and with those measured by Liss et al.

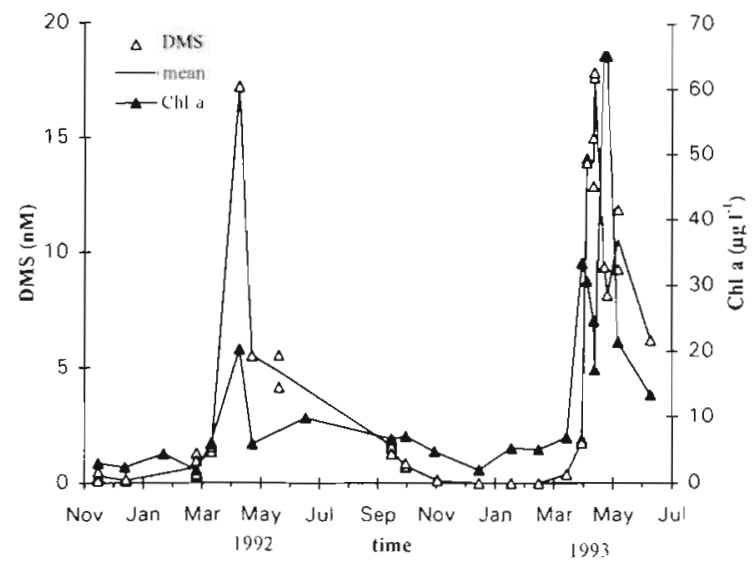

Fig. 2. Seasonal cycle of chlorophyll a and DMS in the Marsdiep (The Netherlands) tidal inlet in 1992 (Series I) and 1993 (Series II). Note different scales for DMS and chl a
(1994) during a series of cruises in the southern North Sea. Our observations, especially those related to the dynamics of the DMS concentrations, are also in accordance with measurements in enclosure experiments with North Sea plankton (Kwint et al. 1993, Kwint \& Kramer 1995, Quist et al. unpubl.). The rapid changes in the DMS concentration mean that the major part of the production of DMS which may escape into the atmosphere is limited to a period of only about $2 \mathrm{mo}$, i.e. in spring and early summer. The limitation to such a short period of DMS fluxes to the atmosphere has major implications for climate modelling Obviously the sampling frequency of the first series was not sufficient to cope with the dynamics of the phytoplankton and DMS related processes. For this reason we will focus our attention on the observations made in 1993 (Series II) in this discussion.

Fig. 3 compares the results of the DMS measurements with the calculated flux to the atmosphere during Series II. The flux to the atmosphere appears to follow the same trend as the water concentration. Differences in the ratio between the calculated flux and DMS water concentration can be attributed to differences in wind speed. The wind speeds observed during the measurement period varied but did not change to such an extent that major differences were found. As daily averaged wind speeds were used in these calculations, it would be possible that relatively large deviations would affect the actual daily fluxes. However, the maximum wind speeds encountered in the period of observation never exceeded $6 \mathrm{~m} \mathrm{~s}^{-1}$. As a result only minor variations in fluxes are to be expected over shorter time scales, since the data are still in the rather horizontal part of the Liss/Slater model (Liss \& Slater 1974). Therefore we used an equilibrium model rather than a dynamic model. The latter would have been more appropriate under more variable wind speed conditions.

A comparison between the results obtained by a micro-meteorological measurement (gradient method) and by the Liss/Slater model calculation agreed well, at

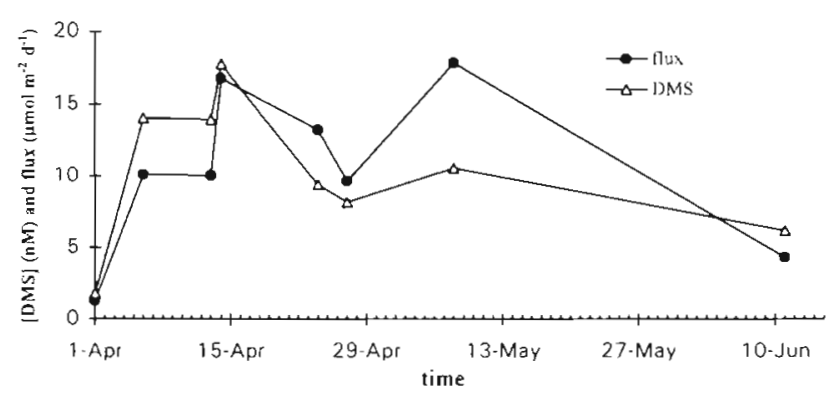

Fig. 3. Comparison of DMS water concentrations and daily flux $\mathrm{m}^{-2}$ during spring 1993 in the Marsdiep tıdal inlet 

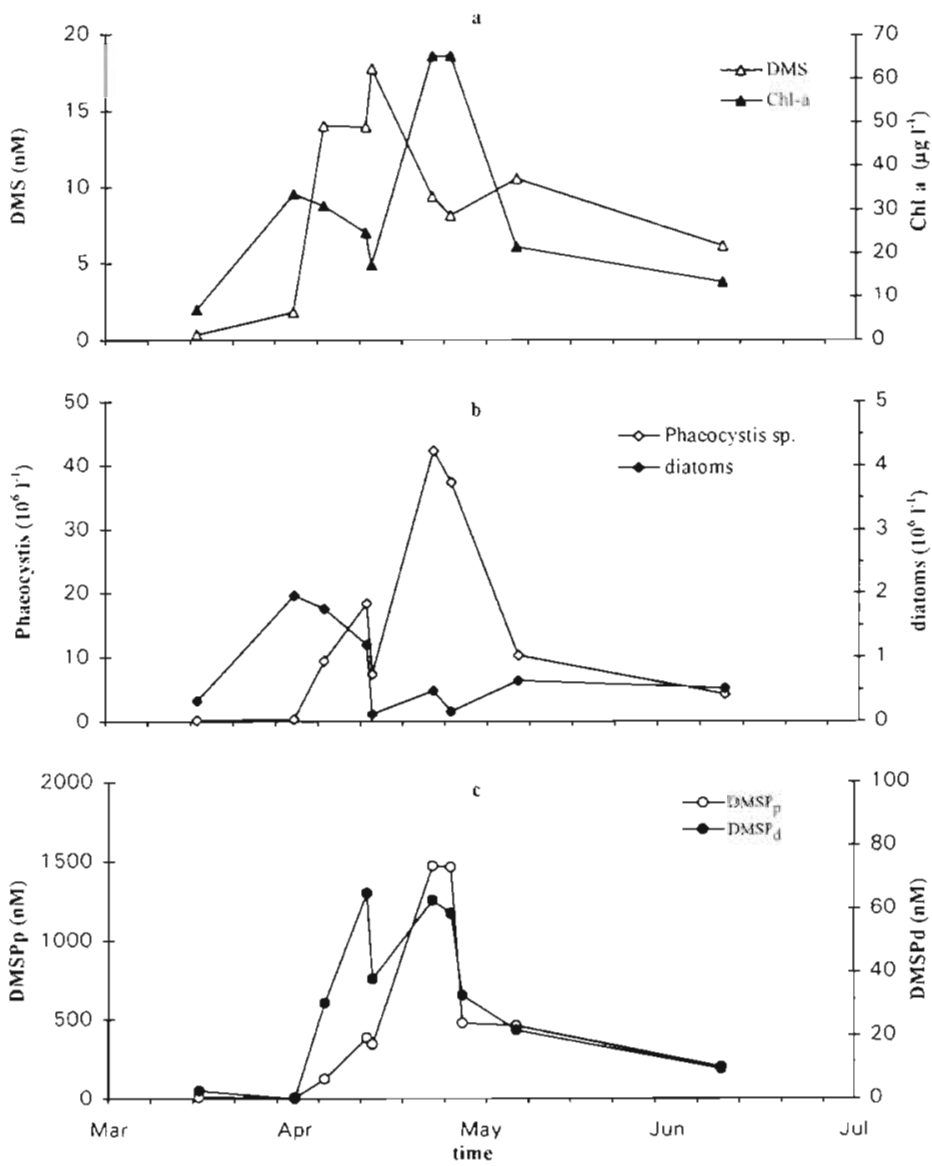

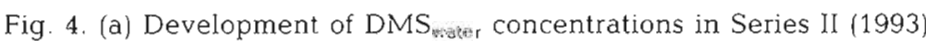
along with the development in chl a concentrations. (b) Development of diatoms $(72 \%$ Skeletonema costatum, $22 \%$ Nitschia closterium and $6 \%$ others), along with development in Phaeocystis sp. numbers during Series II (note difference in scales). (c) Development of dissolved DMSP concentration $\left(\mathrm{DMSP}_{\mathrm{d}}\right)$, along with the development in particulate DMSP concentration (DMSP $)$ during Series II (note difference in scales for DMSP $_{p}$ and DMSP $_{d}$ )

least for the wind speeds observed during these tests (Baart pers. comm.). It is demonstrated in Fig. 3 that the emission of DMS exceeds the background values during a period of only $6 \mathrm{wk}$. In the period 5 April to 10 May 1994 we observed that the calculated flux of DMS ranged from about 10 to $15 \mu \mathrm{mol} \mathrm{m} \mathrm{m}^{-2} \mathrm{~d}^{-1}$. Assuming that the observations are representative for this period of the year, this implies that phytoplankton activity in these coastal waters during the spring period resulted in a total DMS emission of 0.4 to $0.6 \mathrm{mmol} \mathrm{m} \mathrm{m}^{-2}$ into the atmosphere. The total emission per year was calculated to be about $1.17 \mathrm{mmol} \mathrm{m}{ }^{-2} \mathrm{yr}^{-1}$. According to Andreae \& Raemdonck (1983) and Bates et al. (1987) coastal waters in the temperate zone have an emission rate of 1.1 to $1.8 \mathrm{mmol} \mathrm{m}^{-2} \mathrm{yr}^{-1}$. These findings underline the importance of the DMS production during the short spring bloom period.
In order to enhance the resolution of the DMS and chl a concentration development in Series II as depicted in Fig. 2, these results are shown in more detail in Fig. 4. Fig. 4a clearly shows that the DMS concentration increases from approximately 2 to $14 \mathrm{nM}$ in only $1 \mathrm{wk}$. The DMS concentration remained at the same level for another week, with a maximum of approximately $18 \mathrm{nM}$ and then decreased to half this value within $2 \mathrm{wk}$. The chl $a$ development showed 2 successive peaks with an interval of about 2 wk. The highest DMS peak followed the first chl a peak only.

The phytoplankton composition during this period is presented in Fig. 4b. After a first diatom bloom (consisting of $72 \%$ Skeletonema costatum, 22\% Nitschia closterium and $6 \%$ other diatoms) there was a succession towards Phaeocystis sp. (mainly present in colonial form) causing the second peak in chl $a$. It is commonly found in these coastal waters that the initial diatom bloom is succeeded by a Phaeocystis development (Gieskes \& Kraay 1975, Reid et al. 1990). During our observations the Phaeocystis bloom reached a maximum of $42 \times 10^{6}$ cells $\mathrm{l}^{-1}$ in about 3 or $4 \mathrm{wk}$ (Fig, 4b), which appears to be a normal value for these waters (Cadée \& Hegeman 1991). Along with the development of the Phaeocystis cell numbers, a parallel development in DMSP $_{p}$ could be observed. Diatoms are generally considered not to contain a large amount of DMSP but Phaeocystis sp. is known to produce considerable amounts of DMSP (Keller et al. 1989, Liss et al. 1994).

In Fig. 4c the concentrations of DMSP $p$ and $\mathrm{DMSP}_{\mathrm{d}}$ are given. Starting in April, $\mathrm{DMSP}_{\mathrm{d}}$ increased from detection limits $(0.06 \mathrm{nM})$ to $65 \mathrm{nM}$. After an initial drop, the $\mathrm{DMSP}_{\mathrm{d}}$ concentration came back to this level, after which it decreased to about $20 \mathrm{nM}$. DMSP $\mathrm{p}$ rose from 7 to no less than $1500 \mathrm{nM}$ in $4 \mathrm{wk}$, after which a rapid decrease followed to about $500 \mathrm{nM}$ in a few days. This maximum concentration of $\mathrm{DMSP}_{\mathrm{p}}$ is to be considered high for open sea values, but not uncommon in coastal waters with massive plankton (Phaeocystis) blooms (Liss et al. 1994. Stefels et al. 1995). The DMSP $_{p}$ peak coincided with the formation of a peaking of $\mathrm{DMSP}_{\mathrm{d}}$, with a ratio of $\mathrm{DMSP}_{\mathrm{p}}$ to $\mathrm{DMSP}_{d}$ of about 20. The $\mathrm{DMSP}_{d}$ production also coincided with the development of the DMS maximum (Fig. 4a). It is known that the early stages of a Phaeocystis bloom enhance the transformation of DMSP $_{d}$ to DMS through the action of a DMSP-lyase (Stefels \& van Boekel 1993). It was also demonstrated in that paper that DMS was produced only after the 
bloom had peaked (senescence) in (axenic) Phaeocystis cultures, which is not consistent with our findings as we did not find a major release of DMS after the Phaeocystis bloom.

In order to get some idea about the DMSP per unit of biomass, the ratio of $\mathrm{DMSP}_{\mathrm{p}}$ :chl $a$, along with the chl a concentration, are shown in Fig. 5a. It is clear that the ratio of $\mathrm{DMSP}_{\mathrm{p}}$ :chl a changes with the succession of the plankton species, and that this ratio increases steeply with the early development of the Phaeocystis bloom. Once the effects of the contribution of the diatoms to the chl a signal had ceased, a rather constant ratio of DMSP $_{p}$ : chl $a$ of about $20 \mathrm{nmol} \mathrm{\mu g}^{-1}$ was established. This appears even to be true for the situation where the Phaeocystis bloom had passed its maximum. It is well known from the literature that Phaeocystis contain a relatively high amount of DMSP (per biovolume) e.g. in comparison to diatoms (Keller et al. 1989, Liss et al. 1993).

This is represented in Fig. 5b. Here the amount of DMSP $_{p}$ is calculated based on cell densities (Fig. 4b.) and the amounts DMSP cell $^{-1}$ reported in the literature. For diatoms (Keller et al. 1989) and Phaeocystis (Quist et al. unpubl.) 17 fmol cell ${ }^{-1}$ and $34 \mathrm{fmol}_{\text {cell }}^{-1}$ respectively were used (note the difference in scales). It is highly unlikely that the $\mathrm{DMSP}_{\mathrm{p}}$ in the diatoms was responsible for the release of $\mathrm{DMSP}_{\mathrm{d}}$ observed in Fig. 4c. Otherwise the diatoms should be producing large amounts of DMSP that was immediately excreted without use. The Phaeocystis bloom is a resultant of fast growing and decaying cells and it is argued here, that the increase in DMSP ${ }_{d}$ can be attributed to the activity of Phaeocystis alone.

Since the formation of DMS is linked to the existence of DMSP, either by direct transformation or via a route involving the formation of $\mathrm{DMSP}_{\mathrm{d}}$, one would expect that a DMSP peak would eventually yield a high DMS concentration, potentially much higher than the peak observed after the diatom bloom. Surprisingly, the peak in DMSP $_{\mathrm{p}}$ during the Phaeocystis bloom was not followed by a major DMS development.

DMSP $_{p}$ may be transformed directly to DMS by Phaeocystis produced DMSP-lyase. Stefels \& van Boekel (1993) showed that this process is particularly important in the log-phase of a culture, and not during senescence. This process may have resulted in the relatively small but significant increase in DMS concentration in the initial Phaeocystis growth phase. Although some increase could be observed in the formation of DMS after the Phaeocystis bloom (Fig. 4a), the amount does not reflect the large amount total DMSP that was potentially available once the Phaeo-
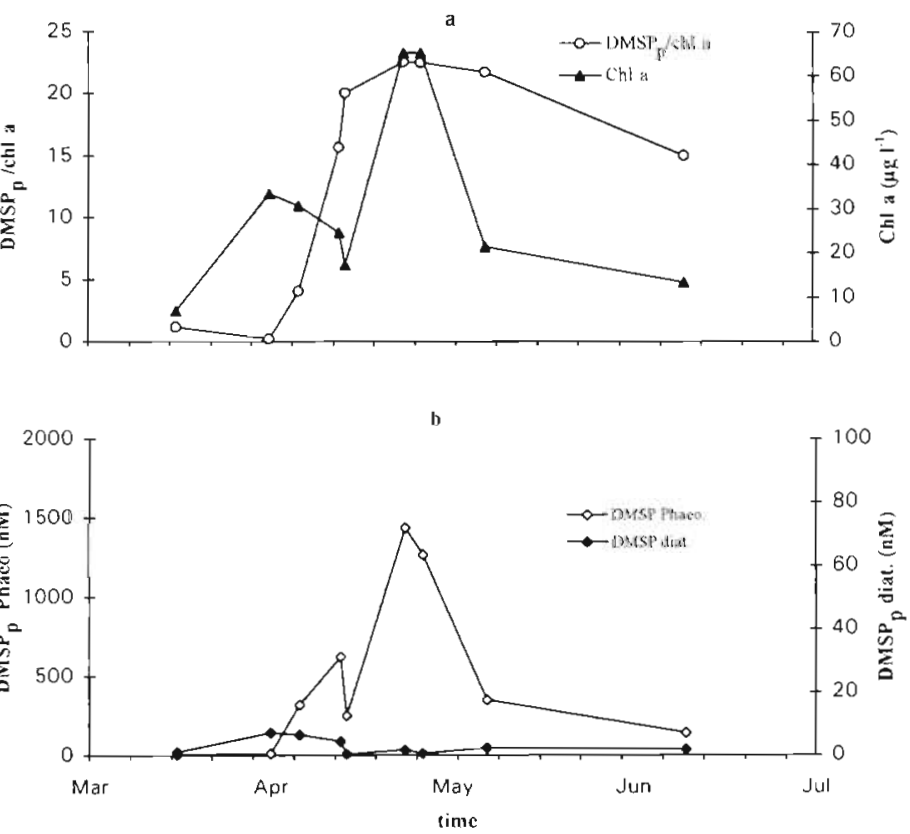

Fig. 5. (a) Comparison of the ratio $\mathrm{DMSP}_{\mathrm{p}}$ : chl a (nmol $\mu \mathrm{g}^{-1}$ ) and the development in chl a during Series II (note different scales). (b) Development of DMSP, concentration in Phaeocystis sp. and diatom cells (note different scales for Phaeocystis sp. and diatoms)

cystis bloom had collapsed in the last week of April. The drop of $1000 \mathrm{nM}$ in $\mathrm{DMSP}_{\mathrm{p}}$ concentration (and the drop of $30 \mathrm{nM} \mathrm{DMSP}$ ) in the last week of April was not at all counterbalanced by the $3 \mathrm{nM}$ DMS increase (Fig. 4a) and/or the calculated flux (Fig. 3). A comparison of the $\operatorname{DMSP}_{p}$ loss per $\mathrm{m}^{2}$ and the calculated sea-air exchange of DMS, assuming an average water depth of $10 \mathrm{~m}$, indicates that the DMS flux consists of only an insignificant fraction in this period: $\mathrm{DMSP}_{\mathrm{p}}$ loss = $10 \mathrm{mmol} \mathrm{m} \mathrm{m}^{-2} \mathrm{~d}^{-1}$. DMS flux $=17 \mu \mathrm{mol} \mathrm{m} \mathrm{m}^{-2} \mathrm{~d}^{-1}$.

A link is obviously missing in the step leading from DMSP $_{p}$ to either DMSP ${ }_{d}$ or DMS. It is not likely that the sampling frequency applied could have caused a major DMS or DMSP peak to be missed considering the width of the DMS peak before the Phaeocystis bloom. The missing sink may have been the result of the (bacterial) transformation of $\mathrm{DMSP}_{\mathrm{p}}$ directly into sulphur compounds that were not analyzed, export of DMSP $_{p}$ out of the system, e.g. by sedimentation of the particulate material (phytoplankton, faecal pellets), or by a fast turnover of DMS and DMSP ${ }_{d}$.

Physico-chemical processes (photochemical oxidation) are not considered to be very important (Brimblecombe \& Shooter 1986). Of course the export of DMSP cannot be excluded. However, the Marsdiep tidal inlet, the adjacent coastal waters and the Wadden Sea are turbulent systems, and it is not likely, therefore, that this mechanism can solely account for the export effect observed. 
Therefore, either the direct or the indirect bacterial transformations seem to be the most dominant routes of DMS and DMSP conversion. Aerobic routes for DMSP transformation include the direct formation of acrylate and DMS (De Souza \& Yoch 1995), the formation of methylmercaptopropionate (MMPA) and the subsequent break down to acrylate and methanethiol, or the DMSP to MPA (mercaptopropionate) route via MMPA (Visscher \& Taylor 1994, Quist et al. unpubl.). Furthermore, a rapid utilization of DMS by bacteria could prevent the accumulation of this compound. DMS consuming bacteria (producing sulphate and $\mathrm{CO}_{2}$ or DMSO) have been isolated (Hansen et al. 1993).

As a result we must assume that the rate of the trans-

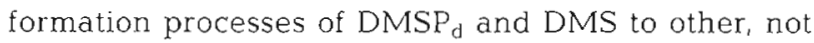
measured, compounds is high. Otherwise we would have detected a large increase in DMS or DMSP ${ }_{d}$ concentration in the samples upon release by or senescence of the Phaeocystis. Due to these fast transformation rates it is difficult to estimate which process and/or route is the most important. Kiene \& Service (1991) and Bates et al. (1994) estimate that only a maximum of $30 \%$ of the DMSP will actually be converted to DMS. Of this DMS pool a major part can be consumed by bacteria (Kiene 1992, Quist et al. unpubl.). The question remains as to why this process of rapid bacterial conversion does not take place during the period when DMS and DMSP accumulate after the diatom bloom. It is postulated here that this may be the result of a change in the bacterial activity and populations.

Bacterial consumption is largely dependent upon the available substrate. For DMS consumers this means that although they will always be present in low densities, the bacterial population will start to increase when sufficient DMS becomes present in the water column (Quist et al, unpubl.). In the initial phase of DMS production, as a result of the diatom senescence, the bacterial population is not yet well

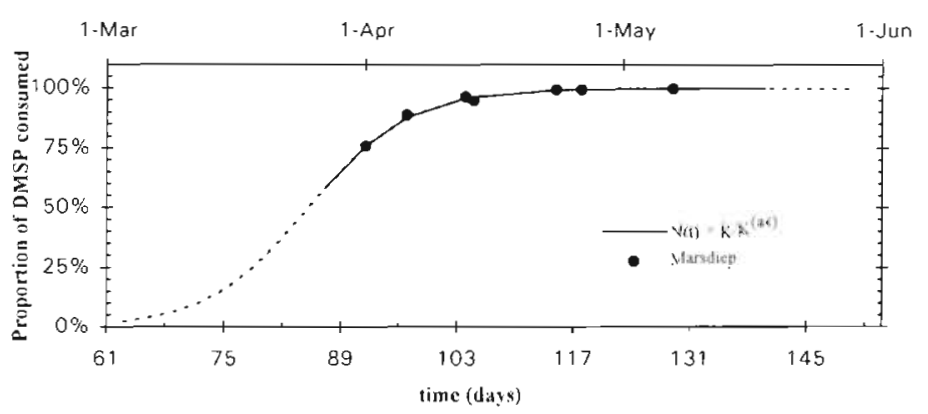

Fig. 6. Proportion of DMSP that is lost from the water column without accumulation of DMS (•) in the Marsdiep channel in Series II. A logistic growth curve (for bacteria) is fitted to the collected data $(-)$ developed. Therefore, a relatively large proportion of the particulate and dissolved DMSP will lead to the formation of DMS (supported by a high DMSP-lyase activity from the initial Phaeocystis bloom). The presence of algal exudates enables a bacterial population to develop rapidly. A well developed bacterial population will be more effective in the facultative transformation of DMS and DMSP . This may result in a situation which was reflected by our field observations: a DMS peak following a diatom bloom (or following the increase of Phaeocystis numbers) and the absence of such high DMS concentrations after the Phaeocystis bloom. The existence of such a process was confirmed in a mesocosm experiment where the actual bacterial DMS and DMSP consumption rates were measured, and where numbers of DMS-utilizing bacteria were measured (Quist et al. unpubl.). In order to elucidate the possible role of bacteria in the conversion of DMS(P), a simple model was constructed. Based on a description of the fraction DMSP $_{p}$ lost from the water column, a curve is fitted assuming a logistic growth curve. This curve is used to simulate bacterial activity during the period of the plankton bloom in the model situation.

The proportion of DMSP that is converted (by bacteria) to other sulphur compounds than DMS can be defined as $\left(\left[\mathrm{DMSP}_{\mathrm{p}}\right]-[\mathrm{DMS}]\right) /\left[\mathrm{DMSP}_{\mathrm{p}}\right]$. This represents a net result as DMS may be well produced but turned over rapidly itself. In Fig. 6 the field data calculated for the Marsdiep channel in April and May are presented. The data points show that not only the over-

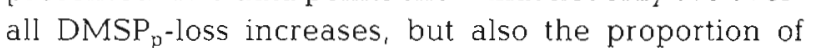
DMSP $_{\mathrm{p}}$ lost from the watercolumn until almost $100 \%$ of the DMSP is consumed at the end of the bloom without DMS accumulation. Assuming a bacterial process, the curve fitted through the field data points in Fig. 6 represents a logistic growth curve not uncommon in microbiology studies, with the equation: $N_{\{l\}}=$ $K / K^{\text {dat) }}$ (Schlegel \& Schmidt 1985), with $N$ representing bacterial numbers, $K$ representing the carrying capacity of the system, a the growth constant and $t$ the time. The simulated growth curve should be considered as a mathematical representation of total loss factors (of which bacterial activity is the major component).

To illustrate our hypothesis that the proportional increase of DMSP consumption is related to bacterial growth more clearly, we apply the logistic increase of DMSP consumption on a curve fitted through the measured DMSP data points in Fig. 7 (solid line, compare with Fig. 4c). When the fraction (percentage) of DMSP that is transformed, as identified by the logistic growth curve (dashed line), is subtracted from this DMSP curve, a new curve appears that represents that 
part of the DMSP that accumulates as DMS (broken line). When the actually measured concentrations of DMS from the field are added, a good agreement can be observed.

Although our model represents a rather simple and speculative approach, we think that it clearly illustrates the potential effects of varying bacterial activities, resulting in an outcome that reflects our findings in the natural system. It suggests a mechanism where a high density of Phaeocystis does not automatically lead to a large production of DMS. Due to the nature of these complex interactions, small shifts in e.g. delayed bacterial activity may easily result in a situation where a massive DMS production follows a Phaeocystis bloom, as has been observed before (Liss et al. 1994).

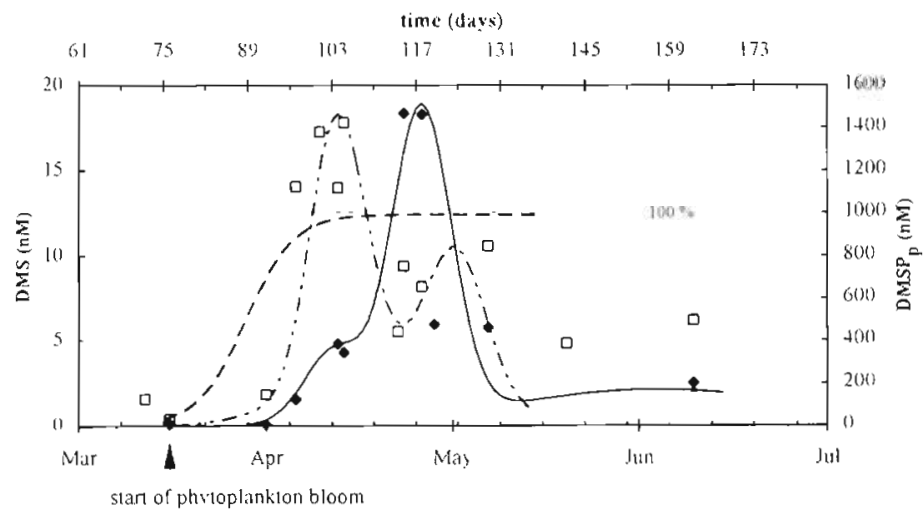

Fig. 7. Graphical representation of bacterial 'loss-factors' for DMS and DMSP. Observed DMS water $_{\text {concentrations }(\square), D \text { DSP }}$ concentrations (-). DMSP fitted curve (-), bacterial 'loss factor' (-- ) and result from subtracting the loss of DMSP from the DMSP fit (-....) (note different scales for DMS and DMSP)

\section{CONCLUSIONS}

The idea is emerging that only during special circumstances does the DMS concentration rise above normal background concentrations. Our results indicate that a considerable part ( 30 to $50 \%$ ) of the annual emission of DMS over the sea/air interface takes place in the time span of about $6 \mathrm{wk}$, closely related to the phytoplankton bloom. The DMS concentration is not contralled by the DMS(P) producers alone but by the balance between production and consumption of DMSP and DMS. Small shifts in bacterial activity or populations can lead to either an increase or decrease in the amount of DMS emitted to the atmosphere.

Although our quantitative results were collected in coastal waters, with a dominant role of Phaeocystis sp., we feel that the mechanisms involved have a universal application. That the major flux of DMS to the atmosphere may be limited to only a short period could have consequences for climate modelling. Furthermore, the fact that bacterial consumption of DMS and DMSP may play the major role in determining the amount of DMS available for ventilation to the atmosphere makes it difficult to predict whether a climate feedback mechanism (Charlson et al. 1987) exists via DMS formation in the oceans.

Acknowledgements. The authors thank Gerrit Hoornsman Marijke van der Meer and Henk Verhagen for their technical assistance; and Piet Roele for teaching us to handle the research vessel 'Nauplius II' This project could not have been carried out without the hospitality of the Department of Analytical Chemistry TNO. Without the expertise of the late Finn 'Bill' Lindquist in the analysis of DMS and related compounds, none of this would have been possible to achieve. The project was supported by the Dutch government (Ministry of VROM) under contract no. NOLK/026/90

\section{LITERATURE CITED}

Andreae MO, Reamdonck H (1983) Dimethylsulfide in the surface ocean and the marine atmosphere: a global view. Science 221:744-747

Bates TS, Cline JD, Gammon RH, Kelly-Hansen SR (1987) Regional and seasonal variations in the flux of oceanic dimethylsulfide to the atmosphere. J Geophys Res 92(C3) 2930-2938

Bates TS, Kiene RP, Wolfe GV, Matrai PA, Chavez FP, Buck KR, Blomquist BW, Cuhel RL (1994) The cycling of sulfur in surface seawater of the Northeast Pacific. J Geophys Res 99(C4):7835-7843

Baumann MEM, Brandini FP, Staubes R (1994) The influence of light and temperature on carbon-specific DMS release by cultures of Phaeocystis antarctica and three antarctic diatoms. Mar Chem 45:129-136

Belviso B, Buat-Menard P. Putaud JP, Nguyen BC, Claustre H, Neveux J (1993) Size distribution of dimethylsulfoniopropionate (DMSP) in areas of the tropical northeastern Atlantic Ocean and the Mediteranean Sea. Mar Chem 44: $55-71$

Belviso S, Kim SK, Rassoulzadegan F, Krajka B, Nguyen BC Mihalopoulos N, Buat-Menard P (1990) Production of dimethylsulfonium propionate (DMSP) and dimethylsulfide (DMS) by a microbial food web. Limnol Oceanogr 35(8): 1810-1821

Brimblecombe P, Shooter D (1986) Photo-oxidation of dimethylsulphide in aqueous solution. Mar Chem 19(4) 343-354

Bürgermeister S, Zimmermann RL, Georgii HW, Bingemer HG, Kirst GO, Jansen M, Ernst W (1990) On the biogenic origin of dimethylsulfide: relation between chlorophyll. ATP, organismic DMSP, phytoplankton species, and DMS distribution in Atlantic surface water and atmosphere. J Geophys Res 95(D12):20607-20615

Cadée GC, Hegeman J (1991) Historical phytoplankton data of the Marsdiep. Hydrobiol Bull 24(2):111-118

Caldeira K (1989) Evolutionary pressures on planktonic production of atmospheric sulphur. Nature 337:732-734

Charlson RJ, Lovelock JE, Andreae MO, Warren SG (1987) Oceanic phytoplankton, atmospheric sulphur, cloud albedo and climate. Nature 326:655-661

Dacey JWH, Blough NV (1987) Hydroxide decomposition of 
dimethylsulfoniopropionate to form dimethylsulfide. Geophys Res Lett 14(12):1246-1249

Dacey JWH, King GM, Wakeham SG (1987) Factors controlling emission of dimethylsulphide from salt marshes. Nature 330:643-645

Dacey JWH, Wakeham SG (1986) Oceanic dimethylsulfide: production during zooplankton grazing on phytoplankton. Science 233:1314-1316

De Souza MP, Yoch DC (1995) Purification and characterization of dimethylsulfoniopropionate lyase from an Alcaligenes-like dimethyl sulfide-producing marine isolate. Appl Environ Microbiol 61(1):21-26

Gibson JAE, Garrick RC, Burton HR, McTaggart AR (1990) Dimethylsulfide and the alga Phaeocystis-pouchetii in Antarctic coastal waters. Mar Biol 104:339-346

Gieskes WWC, Kraay GW (1975) The plankton spring bloom in Dutch coastal waters of the North. Sea. Neth $J$ Sea Res 9: $166-196$

Gröne T, Kirst GO (1992) The effect of nitrogen deficiency, methionine and inhibitors of methionine metabolism on the DMSP contents of Tetraselmis subcordiformis (Stein). Mar Biol 112:497-503

Hansen TA, Quist P, Van Der Maarel MJEC, Dijkhuizen L (1993) Isolation of marine dimethylsulfide-oxidizing bacteria. In: Restelli G, Angeletti G (eds) Dimethylsulphide: oceans, atmosphere and climate. Int Symp Proc Belgirate. Kluwer Acad. Publ, Dordrecht, p 37-42

Keller MD, Bellows WK, Guillard RRL (1989) Dimethyl sulfide production in marine phytoplankton. In: Saltzman ES, Cooper WJ (eds) Biogenic sulfur in the environment. ACS Symposium series 393. American Chemical Society, Washington, DC, p $167-182$

Kiene RP (1990) Dimethyl sulfide production from dimethylsulfoniopropionate in coastal seawater samples and bacterial cultures. Appl Environ Microbiol 56(11): $3292-3297$

Kiene RP (1992) Dynamics of dimethyl sulfide and dimethylsulfoniopropionate in oceanic water samples. Mar Chem $37: 29-52$

Kiene RP, Service SK (1991) Decomposition of dissolved DMSP and DMS in estuarine waters: dependence on temperature and substrate concentration. Mar Ecol Prog Ser $76: 1-11$

Kwint RLJ, Kramer KJM (1995) DMS production by plankton communities. Mar Ecol Prog Ser 121:227-237

Kwint RLJ, Kramer KJM, Baart AC, Verhagen HLM (1993) The production of dimethylsulfide by a plankton community: a mesocosm experiment. In: Restelli $G$, Angeletti $G$ (eds) Dimethylsulphide: oceans, atmosphere and climate. Int Symp Proc Belgirate. Kluwer Acad Publ, Dordrecht, $\mathrm{p}$ $53-62$

Leck C, Larsson U, Bågander LE, Johansson S, Hajdu S (1990) Dimethyl sulfide in the Baltic Sea: annual variability in relation to biological activity. J Geophys Res 95(C3): 3353-3363

Legrand $M$, Feniet-Saigne $C$, Saltzman ES, Germain $C$, Barkov NI, Petrov VN (1991) Ice-core record of oceanic emissions of dimethylsulphide during the last climate cycle. Nature 350:144-146

This article was submitted to the editor
Levasseur M, Keller MD, Bonneau E, D'Amours D, Bellows WK (1994) Oceanographic basis of a DMS-related Atlantic cod (Gadus morhua) tishery problem: blackberry feed. Can J Fish Aquat Sci 51:881-889

Lindquist $F$ (1989) Sulfur-specific detection in air by photoionization in a multiple detector gas chromatographic system. J High Res Chrom 12:628-631

Liss PS Malin G, Turner SM (1993) Production of DMS by marine phytoplankton. In: Restelli $G$, Angeletti $G$ (eds) Dimethylsulphide: oceans, atmosphere and climate. Int Symp Proc Belgirate. Kluwer Acad Publ. Dordrecht, p $1-14$

Liss PS, Malin G, Turner SM, Holligan PM (1994) Dimethyl sulphide and Phaeocystis: a review. J Mar Syst 5:41-53

Liss PS, Slater PG (1974) Flux of gases across the air-sea interface. Nature 247:181-184

Malin G, Turner SM, Liss PS (1992) Sulfur: the plankton/ climate connection. J Phycol 28:590-597

Matrai PA, Keller MD (1993) Dimethylsulfide in a large scale coccolithophore bloom in the Gulf of Maine. Cont Shelf Res 13(8/9):831-843

Matrai PA, Keller MD (1994) Total organic sulfur and dimethylsulfoniopropionate in marine phytoplankton: intracellular variations. Mar Biol 119:61-68

Nguyen BC, Belviso S, Mihalopoulos N, Gostan J, Nival P (1988) Dimethyl sulfide production during natural phytoplanktonic blooms. Mar Chem 24(2):1.33-142

Osinga R, Kwint RLJ, Lewis WE, Kraay GW, Lont JD, Lindeboom HJ, van Duyl FC (1.996) Production and fate of dimethylsulfide and dimethylsulfoniopropionate in pelagic mesocosms. The role of sedimentation. Mar Ecol Prog Ser 131:275-286

Parsons RT, Maita Y, Lalli CM (1984) Determination of nutrients, chlorophylls and total carotenoids: spectrophotometric method. A manual of chemical and biological methods for seawater analysis. Pergamon Press, Oxford, p 3-25, $101-111$

Reid PC, Lancelot C, Gieskes WWC, Hagmeier E, Weichart G (1990) Phytoplankton of the North Sea and its dynamics: a review. Neth J Sea Res 26(2/4):295-331

Schlegel HG, Schmidt K (1985) General microbiology. Univ Press, Cambridge, p 190-197

Stefels J, Dijkhuizen L, Gieskes WWC (1995) DMSP-lyase activity in a spring phytoplankton bloom off the Dutch coast, related to Phaeocystis sp. abundance. Mar Ecol Prog Ser 123:235-243

Stefels J, Van Boekel WHM (1993) Production of DMS from dissolved DMSP in axenic cultures of the marine phytoplankton species Phaeocystis sp. Mar Ecol Prog Ser 97: $11-18$

Turner SM, Malin $G_{1}$ Liss PS (1989) Dimethyl sulfide and (dimethylsulfonio)propionate in European coastal and shelf waters. In: Saltzman ES, Cooper WJ (eds) Biogenic sulfur in the environment. ACS symposium series 393. American Chemical Society, Washington, DC, p 183-201

Visscher PT, Taylor BF (1994) Demethylation of dimethylsulfoniopropionate to 3-mercaptopropionate by an aerobic marine bacterium. Appl Environ Microbiol 60(12): $4617-4619$

Manuscript first received: April 4, 1995

Revised version accepted: November 27, 1995 